\title{
USING THE TRANSPIRATION REGIME TO ESTIMATE BIOMASS PRODUCTION
}

\author{
Viliam Novák1 and Martinus Th. van Genuchten ${ }^{2}$
}

The design and implementation of a new or improved irrigation or drainage system should be preceded by a study of the soil water regime (SWR) to define the need for such a system and to optimize its design. This requires estimates of appropriate parameters characterizing the long-term (multiyear) dynamics of the SWR and its relation to biomass production. Parameters that could be used for this purpose are the water content or pressure head at one or several points in the soil root zone or the average water content of the root zone, as affected by precipitation and evapotranspiration or other variables. Because these variables change from year to year, it is necessary to characterize somehow statistically the SWR during a relatively long period. Because the water content is not easily related directly to biomass production, we used the calculated seasonal transpiration rate as an indirect characteristic of the canopy water regime. This article presents a method for estimating plant production as a function of the seasonal transpiration rate as calculated retrospectively with the HYDRUS-ET software package. New in our approach is the use of an empirical relationship between seasonal transpiration and yield. The cumulative frequency distribution of seasonal transpiration was chosen as the basic characteristic of the SWR as a source of water for plants. The approach allows one to estimate cumulative frequency curves of actual and potential yields. The difference between these two curves is the cumulative frequency distribution of yield to be optimized by the irrigation system. The method permits a better cost-benefit analysis by comparing expected yield increases with the investment and operational expenses of the newly designed irrigation system, or of newly invoked water management practices. The approach is illustrated using a 31-year time series of data for a corn crop (Zea mays L.) grown on loess soil in Slovakia. (Soil Science 2008; 173:401-407)

Key words: Soil water regime, transpiration, biomass production, yield, HYDRUS-ET.

$\mathbf{T}$ HE term soil water regime (SWR) is generally understood to refer in some way to the soil water content, often of the root zone, and its changes with respect to time. Several parameters could be used to numerically characterize the SWR, such as various statistical

Institute of Hydrology, Slovak Academy of Sciences, Račianska 75, 83102 Bratislava 3, Slovakia. Dr. Novák is corresponding author. E-mail: novak@uh.savba.sk

2U.S. Salinity Laboratory, USDA, ARS, 450 W. Bis Springs Rd, Riverside, CA 92507.

Received Oct. 9, 2007; accepted Mar. 19, 2008.

DOI: $10.1097 /$ SS.0b013e318178e739 parameters of the soil water content during the growing season (e.g., mean, variability, temporal correlation, trend, and persistence). Because soil is an inherent part of the soil-plant-atmosphere continuum, the SWR is influenced by many factors such as the physical properties of the soil itself, climatological parameters (e.g., precipitation and evapotranspiration), and possibly depth to groundwater.

Most or all of the previously mentioned processes and parameters affecting the SWR are variable in time and across seasons. To properly characterize the SWR, it is therefore necessary 
to account for the long-time variability of these parameters, which are necessary input to the design and implementation of improved irrigation and drainage practices, and for optimizing the SWR for plant production. As such, the SWR can be compared in many ways with climate in that the variability in meteorological characteristics is often smoothed to produce some characteristic climate.

An early hydrological classification system for the SWR was suggested by Vysockij (1906), and later revised by Rode (1965). A key characteristic of their classification was the direction of the dominant water flux in the soil root zone. Based on the main flow directions, they divided the SWR into percolative, nonpercolative, periodically percolative, and evaporative schemes. A more ecologically based scheme was proposed by Kutílek (1978), who classifies the SWR according to the moisture content of the soil root zone, being in some range between such limits as the permanent wilting point (the water content at a pressure head of $-15,000 \mathrm{~cm}$ ), the point of limited availability of soil water to plants (at $-2500 \mathrm{~cm}$ ), and field capacity (traditionally assumed to be at about $-300 \mathrm{~cm}$ ). Closely related to this is the concept of available water, generally understood to be the difference between the water contents at field capacity and the permanent wilting point, although all of this water may not be equally available to plants (e.g., Letey, 1985; Kirkham, 2005).

Although the approach and related definitions of available water by Kutílek (1978) do allow one to estimate the suitability of the SWR for plant growth on a more general quantitative basis, these methods still are static schemes in that many transient soil and climatological factors are neglected. The aim of this contribution is to propose a method for estimating plant production based on the relationship between seasonal transpiration rate of a particular canopy and biomass production (yield).

\section{THEORETICAL}

Rather than using such indirect proxies as the soil water content or pressure head, we assessed the relationship between biomass production and the SWR in terms of the flux of water through the plant (i.e., the transpiration rate). Budagovskij and Grigorieva (1991) previously proposed the transpiration rate (daily or seasonal) as the basic characteristic of soil water when viewed as a source for the biosphere. They used the ratio $\eta_{p}$ of actual transpiration $\left(E_{t}\right)$ to potential transpiration $\left(E_{t p}\right)$ to quantify the degree of availability of soil water for a crop canopy as follows:

$$
\eta_{p}=\frac{E_{t}}{E_{t p}}
$$

This criterion is based on the assumption that only the water flux through the plant will participate in the biomass production process. Although soil water is the source of most water used by the biosphere and can be exploited by plants, its presence as such in the soil does not imply its immediate or even eventual use for biomass production.

A quantitative assessment of the influence of soil water in the soil root zone on biomass production can be made using well-known and widely accepted empirical relationships between biomass production (yield) and total transpiration during the growing season of a given crop (Hanks and Hill, 1980; Vidovič and Novák, 1987; Feddes et al., 1999; Kirkham, 2005). These relationships, generally thought to be approximately linear, are valid for a particular plant (canopy) at a particular site subject to standard tillage and nutrition conditions. The only transient characteristic is the transpiration rate as influenced by local meteorological conditions and soil water. The relationship between biomass production (yield) and the seasonal transpiration rate can be expressed by the linear equation:

$$
Y=k_{t} E_{t}-Y_{0}
$$

where $Y$ is dry biomass produced per unit area $\left(\mathrm{t} \mathrm{ha}{ }^{-1}\right), k_{t}$ is the slope of the relationship $\left(\mathrm{t} \mathrm{ha}^{-1}\right.$ $\mathrm{cm}^{-1}$ ), referred to as the crop water use efficiency by Hillel and Guron (1973). $E_{t}$ is the transpiration total over the growing season of the particular canopy $(\mathrm{cm})$, and $Y_{O}$ denotes the intersection of Eq. (2) with the vertical axis $\left(\mathrm{tha}^{-1}\right)$.

Having Eq. (2) for a given site, and knowing the transpiration total of the particular canopy for each growing season as calculated retrospectively for a reasonably long period (cf, climatological studies usually cover at least 20 years), it is possible to calculate cumulative frequency curves of both potential and actual yield. The difference between these two curves is the potential increase in yield that could be realized by optimizing the SWR through irrigation. 


\section{APPLICATION}

Eq.(2) was applied to a large database of information obtained for the Most pri Bratislave site located $5.5 \mathrm{~km}$ east of the city of Bratislava $\left(48^{\circ} 08^{\prime} \mathrm{N}, 17^{\circ} 16^{\prime} \mathrm{E}\right)$ in the northwestern part of the Žitný ostrov region of Western Slovakia. The loamy soil in the area, classified as a chernozem (Food and Agriculture Organization classification), is relatively homogeneous in the upper $1.5 \mathrm{~m}$. A thick layer of Danube-originated gravel is located below this soil layer. This and the fact that the groundwater table generally oscillates between 6 and $8 \mathrm{~m}$ below the soil surface indicate that capillary rise did not influence the water content in the root zone. This section gives a brief synopsis of the model and data used in our study.

\section{Retrospective Modeling}

Long-time series of the SWR were estimated by retrospective modeling. The simulations were carried out assuming constant plant and soil properties, with only the meteorological data allowed to change. We used the Windows-based HYDRUS-ET software package (Šimůnek et al., 1997) for our modeling. HYDRUS-ET is an early modification of the HYDRUS-1D code of Šmůnek et al. (1998), but with more flexible provisions for calculating root water uptake and transpiration. The code uses the Richards equation to simulate water flow in variably saturated systems, whereas convection-dispersion-type equations are used for both heat and solute transport. The evapotranspiration rate and its components (transpiration and evaporation) in HYDRUS-ET are calculated with the modified Penman-Monteith equation (Novák, 1995; Allen et al., 1998) using standard meteorological data and specific information about different types of plant canopies. Potential transpiration rates were estimated first, after which actual rates are calculated from soil actual water content distributions as described in the user manual (Šimůnek et al., 1997). Transpiration was further used to estimate root extraction patterns, expressed by means of a sink term in the Richards equation. The HYDRUS-ET also contains procedures for calculating the interception by plants of rainfall and/or irrigation water. Details are in the HYDRUS-ET user manual (Šimůnek et al., 1997).

\section{Site Description and Soil Properties}

The soil profile at the Most pri Bratislave site was sampled at depths of 10, 20, 30, 50, 70, and $100 \mathrm{~cm}$ below the soil surface using metal cylinders of $100-\mathrm{cm}^{3}$ volume each. Altogether, 33 vertical profiles were sampled involving three profiles at each of 11 sampling events to characterize spatial variability in the soil hydraulic properties. Basic soil characteristics were determined in the laboratory. They included soil water content distributions versus depth and saturated hydraulic conductivities using the falling pressure head method. Desorption branches of the soil water retention curves relating the water content $(\theta)$ and the pressure head $(h)$ were measured using standard pressure cell methods (e.g., Dane and Hopmans, 2002). The measured $\theta(h)$ data were subsequently fitted with the retention equation of van Genuchten (1980), whereas unsaturated soil hydraulic conductivities were calculated using the Mualem model (Mualem, 1976; van Genuchten, 1980). Soil hydraulic parameters used in the HYDRUS-ET calculations are listed in Table 1.

\section{Meteorological Data and Plant Characteristics}

Meteorological data for the simulations were obtained at a meteorological station near the experimental site. The soil water dynamics at the site (soil water contents, pressure heads, daily evaporation, and transpiration rates) was modelled for three crops: corn (Zea mays L.), winter wheat (Triticum aestivum L.), and spring barley (Hordeum vulgare L.), which were the representative crops during the growing seasons of 1971 through 2000, and 2003. The various field measurements were carried out only in 2003 .

TABLE 1

Soil characteristics for the loess soils at the Most pri Bratislave site, Slovakia

\begin{tabular}{ll}
\hline Soil hydraulic parameters & \\
\hline$\theta_{v}, \mathrm{~cm}^{3} \mathrm{~cm}^{-3}$ & 0.18 \\
$\theta_{l a}, \mathrm{~cm}^{3} \mathrm{~cm}^{-3}$ & 0.28 \\
$\theta_{f c}, \mathrm{~cm}^{3} \mathrm{~cm}^{-3}$ & 0.35 \\
$\theta_{s}, \mathrm{~cm}^{3} \mathrm{~cm}^{-3}$ & 0.40 \\
$K_{s}, \mathrm{~cm} \mathrm{~d}^{-1}$ & 4.86 \\
$\alpha, \mathrm{cm}^{-1}$ & 0.0577 \\
$n$ & 1.30 \\
\hline
\end{tabular}

$\theta_{v}$ : water content at the wilting point $(-15,000 \mathrm{~cm}) ; \theta_{l a}:$ water content corresponding to the point of limited availability of soil water to plants $(-2500 \mathrm{~cm}) ; \theta_{f c}$ : water content corresponding to field capacity $(-300 \mathrm{~cm}) ; \theta_{s}$ : saturated water content; $K_{s}$ : saturated hydraulic conductivity; $\alpha$ and $n$ : van Genuchten water retention coefficients. 
The growing seasons of the crops, assumed to be identical to the transpiration periods, were defined as the period between appearance of the first green part of the plant and physiological maturity. Corn (for which the method will be demonstrated here) transpired between May 5 and September 16 for the climatic conditions of southern Slovakia. The exact transpiration time depends in general on the local climate conditions (precipitation, air temperature, air humidity, sunshine duration, wind velocity). The average air temperature of the growing season was $18.3^{\circ} \mathrm{C}$. The site was found to be very suitable for corn production.

\section{HYDRUS-ET Input Data} follows:

The Hydrus-ET model input data were as

\section{Meteorological Data}

Average daily air temperature, water vapor pressure of the air, wind velocity (at 2-m height), daily precipitation rates, and daily sunshine duration, all measured at standard height.

\section{Plant Characteristics}

Plant (canopy) height, leaf area index, rooting depth (as a function of time), canopy roughness, canopy albedo. All of these data were measured directly in the field.

\section{Soil Characteristics}

The initial water content distribution was measured at the beginning of the growing season in 2003. We assumed the same initial distribution for all 30 simulated seasons. The soil profile was assumed homogeneous. We used the desorption branch of the water retention curve because this gave soil water content distributions close to the measured values (Novák and Gallová, 1998). Calculated water content profiles obtained with HYDRUS-ET during 2003 compared well with observed values (results not further shown here).

\section{RESULTS AND DISCUSSION}

Retrospective modeling with HYDRUSET produced daily average values of the soil water content and pressure head at selected depths in the soil profile. Figure 1 shows seasonal distributions of 5-day average soil water pressure heads at a depth of $50 \mathrm{~cm}$ for the corn crop during different seasons. For completeness, we also included the pressure heads at field capacity $(-300 \mathrm{~cm})$ and the limited water availability $(-2500 \mathrm{~cm})$. The seasonal distributions of the pressure head showed considerable variability among the seasons, thus illustrating the need to characterize the long-time SWR in statistical terms. The year 2003 was an especially very dry year.

As discussed earlier, actual biomass production (yield) can be estimated by using the empirical relationship $Y=f\left(E_{t}\right)$, and potential yields (i.e., yields where soil water is not limiting the transpiration rate) using $Y_{p}=$ $f\left(E_{t p}\right)$, where $Y_{p}$ is the potential yield, and $E_{t p}$ is the potential transpiration total during the growing season. For the corn canopy at Most pri Bratislave (Fig. 2), we obtained the following relationship for $Y=f\left(E_{t}\right)$.

$$
Y=0.71 E_{t}-2.4
$$

Eq.(3) is valid within the range of calculated seasonal transpiration rates $\left(7.5<E_{t}<17.1 \mathrm{~cm}\right)$ for the 31 growing seasons. Corresponding

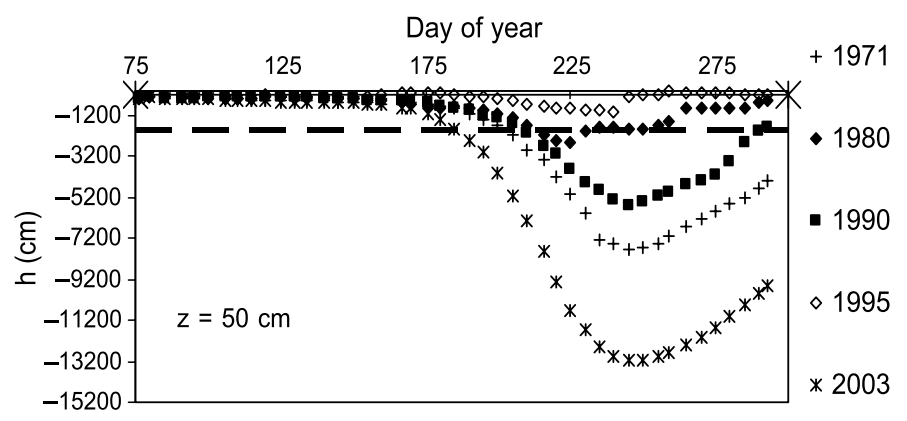

Fig. 1. Seasonal courses of the soil water pressure head $h(\mathrm{~cm})$ at $50-\mathrm{cm}$ depth as calculated with HYDRUS-ET for a corn crop grown at the Most pri Bratislave site in southern Slovakia. Results are presented for six seasons, with each data point presenting 5-day averages. The solid $(-300 \mathrm{~cm})$ and dashed $(-2500 \mathrm{~cm})$ lines represent limits of the range of limited availability of soil moisture for plants. 


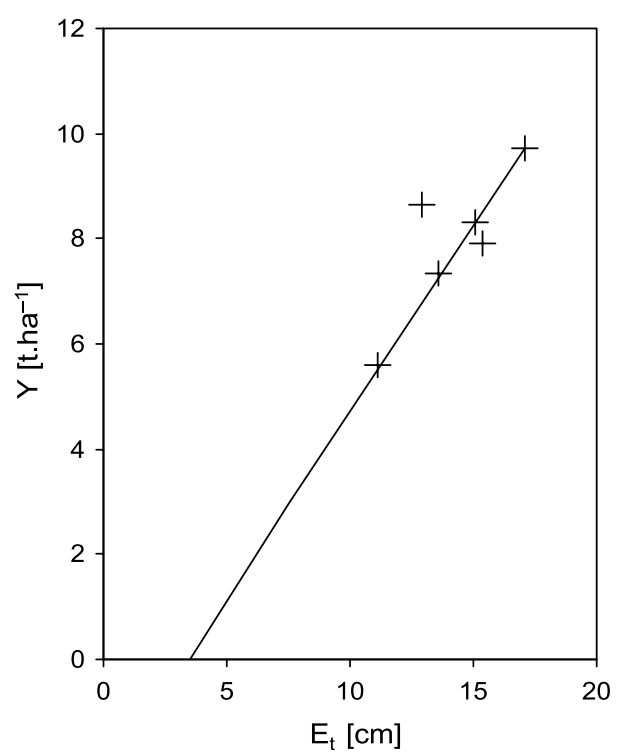

Fig. 2. Plot of the mass of corn grain yield ( $y$ ) versus transpiration total $\left(E_{t}\right)$ during the growing season at the Most pri Bratislave site in Slovakia. The empirical relationship represents six seasons within the period 1971-2000 and 2003.

measured grain yields (for 6 seasons only) of corn were $4.0<Y<9.7 \mathrm{t} \mathrm{ha}^{-1}$. Considerable care should be taken when extrapolating outside of these ranges. Seasonal transpiration totals substantially below the lower limit of the measurement range may well lead to very unrealistic estimates of plant yield.

Figure 3 shows exceedance curves of the corn canopy seasonal transpiration total $\left(E_{t}\right)$ and the potential transpiration total $\left(E_{t p}\right)$, as well as the difference $(\Delta E)$, for the years $1971-2000$ and 2003. Application of Eq.(3) to the data in Fig. 3 leads to estimates of the actual corn grain yield
$(Y)$ and the potential yield $\left(Y_{p}\right)$, and of the corresponding difference $(\Delta Y)$. This difference is the maximum increase in grain yield that can be expected by optimizing the SWR to cause corn to transpire at the maximum (potential) rate for the given meteorological conditions. The resulting exceedance curves of the corn grain yield are plotted in Figure 4. The differences between the potential and actual transpiration (Fig. 3) and yield (Fig. 4) totals were generally relatively small, except for the 2003 season, which was extremely hot and dry. The local climate hence was relatively stable over the 31-year period of study, except for 2003.

The average corn grain yield $(Y)$ was estimated to be $7.64 \mathrm{t} \mathrm{ha}^{-1}$, and the average potential yield $\left(Y_{p}\right)$ was $9.03 \mathrm{t} \mathrm{ha}^{-1}$. This means that the difference was $\Delta Y=1.4 \mathrm{t} \mathrm{ha}^{-1}$, which represents $18 \%$ of the average yield. The question now arises whether it would be reasonable (cost-effective) to design and operate an irrigation or drainage system that will optimize the SWR, such that the dry grain yield increases by some or all of the 1.4-t $\mathrm{ha}^{-1}$ difference. We note that our method is illustrated here using an example involving relatively favorable climatic conditions. More significant differences between $Y$ and $Y_{p}$ are to be expected for drier climates and for soils having lower water-holding capacities (coarsetextured soils).

Alternative approaches to characterize soil water availability to plants may be based on long-time field measurements or by using models for crop growth. Direct field monitoring is probably too cumbersome and expensive for most applications. Crop growth modeling may well be a viable alternative, provided that the generally large number of input parameters

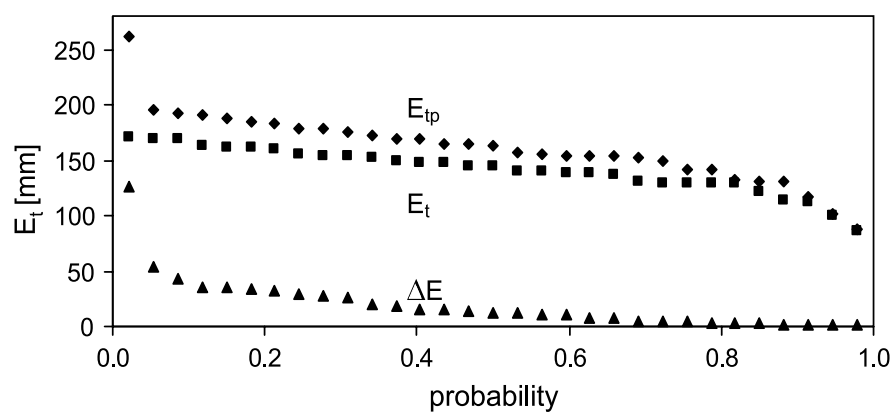

Fig. 3. Exceedance curves of the seasonal transpiration total of the corn canopy $\left(E_{t}\right)$ and the potential transpiration rate $\left(E_{t p}\right)$, and the difference $(\Delta E)$, for the years 1971-2000 and 2003 at the Most pri Bratislave site, Slovakia. 


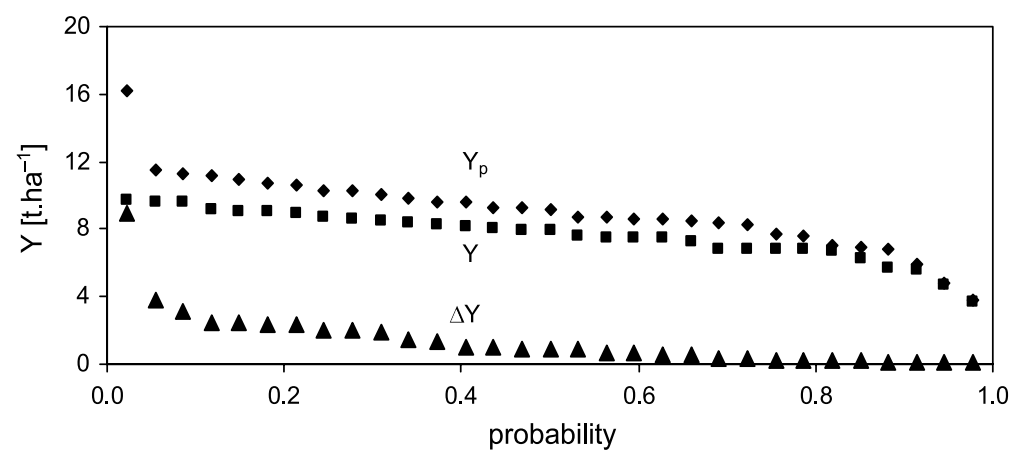

Fig. 4. Exceedance curves of the corn grain yield $(y)$ and the calculated potential yield $\left(Y_{p}\right)$, and the difference $(\Delta y)$, for the 1971-2000 and 2003 growing seasons at Most pri Bratislave, Slovakia.

needed for such models can be quantified properly. By comparison, our method is relatively simple, needs only standard input data, and can be used in combination with any model that calculates the transpiration rate. Hence, rather than HYDRUS-ET, one could use such other models as GLOBAL (Majerčák and Novák, 1992) or SWAP (Huygen et al., 1997) for this purpose. The method allows one to compare design, construction, and operational expenditures with additional income from the increase in potential yield, and hence to evaluate potential profits or losses. Thus, the question becomes an economic one: Is the additional income of the expected yield increase sufficient to cover the increased design and operational expenses?

\section{CONCLUSIONS}

The proposed method for estimating biomass production depends on seasonal transpiration totals as calculated retrospectively with a mathematical model. The method is based on the widely accepted empirical linear relationship between biomass production (yield) and the seasonal transpiration total of the canopy being considered. The procedure should be applicable to any given canopy, site, and invoked set of agricultural management (e.g., tillage and nutrient) practices. The proposed approach was illustrated using a corn canopy grown on a loess soil but should be applicable to any canopy and soil combination.

Using cumulative frequency curves for the seasonal transpiration total, the cumulative frequency curves of actual and potential biomass production can be evaluated using Eq.(2). Potential increases in yields as a result of optimizing the SWR can subsequently be estimated. We note that the methodology holds for a given canopy because transpiration rates will be different for different canopies mainly because of differences in the length of the growing seasons involved and the different periods during which the crops are grown in a particular year (winter cereals, corn, alfalfa [Medicago sativa L.]). The method allows one to compare the design, construction, and operational expenditures needed to optimize transpiration so as to reach potential yields, thus leading to estimates of the increase in income and of potential profits or losses associated with the new irrigation system.

\section{ACKNOWLEDGMENTS}

The authors thank the Slovak Grant Agency VEGA (Grant No. 2/4066/24) and APVV (No. 51-030205) for partial support of this work. This article is further based on work supported in part by Sustainability of Semi-Arid Hydrology and Riparian Areas under the STC Program of the US National Science Foundation (Agreement No. EAR-9876800).

\section{REFERENCES}

Allen, R. G., L. S. Pereira, D. Raes, and M. Smith. 1998. Crop evapotranspiration. Irrig. Drain. Paper No. 56, FAO, Rome, p. 300.

Budagovskij, A. I., and N. I. Grigorieva. 1991. The way to improve effectiveness of soil water resources utilization [in Russian]. Vodnye resursy. 1:131-142.

Dane, J. H., and J. W. Hopmans. 2002. Pressure plate extractor. In: Methods of Soil Analysis, Part 4. Physical Methods. J. H. Dane and G. C. Topp (eds.). Soil Sci. Soc. Am., Inc., Madison, WI, pp. 688-690.

Feddes, R. A., R. W. R. Koopmans, and J. C. van Dam. 1999. Agrohydrology. Wageningen Univ., Dept. Water Resources, p. 205. 
Hanks, R. J., and R. W. Hill. 1980. Modeling crop responses to irrigation in relation to soils, climate and salinity. Int. Irrig. Inform. Center, Publ. No. 6, Bet Dagan, Israel, p. 57.

Hillel, D., and Y. Guron. 1973. Relation between evapotranspiration rate and maize yield. Water Resour. Res. 9:743-748.

Huygen, J., J. C. Van Dam, J. G. Kroes, J. G. Wesseling. 1997. SWAP 2.0: input and output manual, Wageningen Agric. University, and DLO-Staring Centrum, Wageningen, p. 52.

Kirkham, M. B. 2005. Principles of Soil and Plant Water Relations. Elsevier Academic Press, New York.

Kutílek, M. 1978. Soil Science in Water Management (Vodohospodarska Pedologie), 2nd Ed. SNTL [in Czech], State Publisher of Technical Literature, Prague, p. 295.

Letey, J. 1985. Relationship between soil physical properties and crop production. Adv. Soil Sci. 1:277-294.

Majerčák, J., and V. Novák. 1992. Simulation of the soil-water dynamics in the root zone during the vegetation period: I. Simulation model. Vodohospod. Cas. 40:299-315.

Mualem, Y. 1976. A new model for predicting the hydraulic conductivity of unsaturated porous media. Water Resour. Res. 12:513-522.

Novák, V. 1995. Evaporation and Methods of Its Calculation [in Slovak]. VEDA Publisher, Bratislava, Slovakia, p. 260.

Novák, V., and C. Gallová. 1998. Mathematical modelling of annual soil water content changes and sensitivity of the model to soil hydraulic characteristics [in Slovak with English summary]. J. Hydrol. Hydromech. 6:432-446.

Rode, A. A. 1965. Basics of Soil Hydrology, I. Gidrometeoizdat. [in Russian]. Leningrad, Russia.

Šimůnek, J., K. Huang, M. Sejna, Th. M. van Genuchten, J. Majerčák, V. Novák, J. Šútor. 1997. The HYDRUS-ET software package for simulating the one-dimensional movement of water, heat and multiple solutes in variablysaturated media. Version 1.1. Institute of Hydrology, Slovak Academy of Sciences, Bratislava, Slovakia, p. 184.

Šimůnek, J., K. Huang, M. Šejna, and M. T. van Genuchten. 1998. The HYDRUS-1D software package for simulating the one-dimensional movement of water, heat and multiple solutes in variably-saturated media. Version 1.0. IGWMCTPS-70, Int. Ground Water Modeling Center, Colorado School of Mines, Golden, CO, p. 186.

van Genuchten, M. Th. 1980. A closed-form equation for predicting the hydraulic conductivity of unsaturated soils. Soil Sci. Soc. Am. J. 44: 892-898.

Vidovič, J., and V. Novák. 1987. The relation between maize yield and canopy evapotranspiration [in Slovak with English summary]. Rostlinna výroba. 33:663-670.

Vysockij, G. N. 1906. About the oroclimatic basis of soil classification [in Russian]. Pochvovedenie, No. 1. 